\title{
Gender and Entrepreneurship in Uganda: Women Manoeuvring Economic Space
}

\author{
Julius Kikooma \\ Makerere University, \\ Uganda
}

\section{Introduction}

Despite the vastness and depth of the entrepreneurship literature, there is a gap between women's experiences of the phenomenon and what explanations traditional research is producing in academic setting. This means that explanations of entrepreneurial experiences remain largely rooted in orthodox perspectives focused on comparisons of male and female entrepreneurs. Yet such an approach does not illuminate how and why entrepreneurship came to be defined and understood in relation to the behavior of only men.

Inadequacies in comprehending the phenomenon of entrepreneurship by the orthodox approaches have led to the criticism that the concept of entrepreneurship is discriminatory (Billig, 1994), gender-biased (Moore, 1990; Stevenson, 1990), ethnocentrically determined, and even in some respects ideologically controlled (Armstrong, 2001; Ogbor, 2000). More specifically, Ogbor (2000) argued that the discourse on entrepreneurship can potentially sustain not only prevailing societal biases, but also serve as a tapestry for unexamined and contradictory assumptions and knowledge about entrepreneurs. Feminist critics have similarly pointed out weaknesses in the ability of the orthodox frameworks in small business and entrepreneurship research to advance theories relevant to women's experiences. Moreover, despite appeals by researchers (Davidson \& Wilklund, 2001; Low \& MacMillan, 1988; Shane \& Venkataraman, 2000) for alternative approaches, many problem formulations and research themes in the entrepreneurship literature are mainly approached from a particular paradigmatic orientation.

The above arguments suggest that while the research on female entrepreneurship has provided much insight into the behaviours and characteristics of some women business owners, much of the focus has remained on strategies through which female entrepreneurs can mimic the male norm. Such an orientation is guided by an interest in sex-equality, defined as women's similar access to success in business ownership as men's. Citing the limitations that have been recognized with these basic approaches to the study of women and gender which initially looked promising, Ahl (2006) argued that they are inadequate for understanding gender and women's activities. Ahl's argument was that the women's own perspectives are lost in these strategies of adding women, not merely by their under- 
representation in research, but by the fact that whenever they are represented, they are represented in the terms controlled by the dominant groups, rather than their own terms and with their own voice.

Against that background, although women have been included in a number of studies on entrepreneurship in recent years, there has been little focus on challenging traditional definitions of entrepreneurship or in developing new methods to collect information on entrepreneurship. As such, while there has been some reflection on the difference which the sex of the business owner makes, this reflection has not been contextualized within theoretical understandings of the ways in which entrepreneurial work is socially constructed. That is the ways in which entrepreneurial work is situated within gendered processes which form and are formed through relationships between work, organizational structure and the sex of the entrepreneur.

\section{Doing gender and entrepreneurship}

Discussions in the previous section made reference to problems involving culture and gender in relation to the entrepreneurial experiences of entrepreneurs in contexts different from those on which much of the dominant discourses are based. As such the case for linking gender and culture in the analysis of activities of entrepreneurs is a compelling one. That is, it's pertinent to focus on ongoing and context specific practices and the relationships that are created through them. In this case (with respect to the study on which this chapter is based), what else are Ugandan women and men doing under the mantle of entrepreneurship discourses?

The argument has long been made that gender is culturally determined. Oakley (cited in Mills, 1988), for example, distinguished between sex and gender, arguing that sex refers to basic physiological differences between men and women, while gender refers to culturally specific patterns of behaviour which may be attached to the sexes. In other words, gender refers to a set of assumptions about the nature and character of the biological differences between males and females; assumptions that are manifest in a number of ideas and practices which have a determinant influence upon the identity, social opportunities and life experiences of human actors (Mills, 1988). In respect to entrepreneurship, they are assumptions that have tended to be taken for granted in discourse and praxis (Ogbor, 2000). This has led to calls for a shift in epistemological position to the study of entrepreneurship (Steyaert \& Hjorth, 2007; Rindova, Barry \& Ketchen, 2009). Along with others in the entrepreneurship literature (e.g. Blake \& Hanson, 2005), the work of Bruni, Gherardi, and Poggio $(2004 a, b)$ which used feminist theorizing are good examples to this effect. Bruni et al. $(2004 a, b)$ argue that gender and entrepreneurship become mutually constituted through gendered practices performed on a daily basis. That is, doing entrepreneurship is also doing gender. Inspired by such approaches to entrepreneurship scholarship, this chapter takes the social constructionist approach to feminist theorizing as appropriate for these purposes. First, all feminist theorizing is premised on the assumption that gender is fundamental in the structuring of society, with women being historically disadvantaged, and it seeks to end this condition. To this end feminist scholars critically analyse social agendas and consider all forms of knowledge (including that of entrepreneurship) as advancing the interest of some and not others (Harding 1991). As such feminist theorizing offers possibilities for critical 
scholarship which can encourage reflexive theoretical analyses when researching entrepreneurship.

Second, feminist theories are not only about 'women's' issues (i.e., studying women qua women) (Maynard, 2004a). Rather, by using feminist theories as conceptual lenses, a more inclusive social research practice, one that brings in the concerns of others, not just women, who are directly effected by global social and cultural practices and discourses, can be created (Maynard, 2004a, b). In Africa diverse perspectives on feminism can be found in the contemporary literature (Lewis, 2001). Indeed a range of perspectives are encompassed by feminist scholarship in Africa (Arnfred, 2004; Lewis, 2001; Sadiq, 2002). Recurring themes include the divide between continental Africans and those in the diaspora, the diversity in 'African' feminisms which includes womanists (Kolawole, 1997), black feminists, African feminists, or post-colonial feminists (Pereira, 2002; Touré, Barry, \& Diallo, 2003); and varying forms of engagement with 'Western' feminism. However, what is crucial to the question of how women in different socio-cultural and historical locations organize, around what kinds of issues, whether or not they view their activities as feminist, and if so, how they formulate their relations to feminism, is that their struggles have been not only a response to oppressive features of their own societies, but also a fight against the imposition of Western norms (Pereira, 2002).

Those who advance social constructionist ontology argue that a focus on gender relations brings the analyst's attention not simply to the sex of participants as embodied actors but to the cultural production of their subjectivities and material production of their lives (Ahl, 2006). From these processes emerge power-laden, contested, and ever changing social terrains where diverse interests play out (Calàs, Smircich, Bourne, 2009). In terms of entrepreneurship, as Calàs etal (200) suggested, two questions come to the fore: in which ways is entrepreneurship implicated in those gendering processes and practices? What else can be revealed about entrepreneurship through analyses of those processes? Using examples from Uganda, the next sections focus on contextual dynamics in entrepreneurship that are less visible in the extant entrepreneurship literature.

\section{The study}

\subsection{Context}

According to the report by the Uganda Bureau of Statistics (2007) on the Uganda Business Register of 2006/2007, informal sector businesses constitute the largest number of businesses in Uganda. This is particularly the case in the trade sector into which over $60 \%$ of the national businesses fall. As the report observed, the informal sector has turned out to be very important in terms of employment creation. Despite quantitative measurement of the contributions of female micro-entrepreneurs to the GDP being slow in coming, the trading and services sectors (especially food and beverages, textiles, retail trade, pottery), which have led to the high rate of economic growth in the informal economy (Global Entrepreneurship Monitor [GEM] Uganda 2004 Executive Report), are areas of female dominance.

In Uganda, the history of women's entry into the business world in some ways parallels, but is distinct from, that of men. As Snyder (2000) noted, the contemporary story of 
female entrepreneurs in Uganda is also the story of the country's experience of, and recovery from, civil war and its legacy of death, destruction and fear. In terms of explaining the rise in women's entrepreneurship, Uganda's case is unique because "a veritable explosion of Ugandan African entrepreneurship was born out of the need to survive amidst chaos" (Snyder, 2000; p. 17), since the civil wars and economic crises that engulfed the country in the 1970s and early 1980s had such profound demographic and structural impacts.

\subsubsection{Gender ideology ${ }^{1}$ and the challenges to female entrepreneurship in Uganda}

In Uganda, men and women are connected through kinship relationships that, in turn, are nested in broader structural domains, such as ethnic groups and classes (Ssetuba, 2002; Tadria, 1987; Wakoko \& Lobao, 1996). The values and beliefs generated by this system create gender differences in social behaviours, and at the same time reinforce and maintain the status quo in terms of economic and social relations (Tadria, 1987). In Uganda, these distinctions are articulated in proverbs, jokes and myths, and in informal and formal discussions (Ssetuba, 2002). In contrast to other African nations, where gender ideologies stress the role of women as both producers and reproducers (Overa, 2003), in Uganda Tadria (1987) noted that a woman's worth is measured first in terms of what she can offer to family survival. That is, in terms of procuring and processing food (Tadria, 1987). In addition, childbearing is considered an added advantage in marriage. Following this tradition, and as a result of the fact that a high proportion of women live in rural areas, over time Ugandan women have come to provide $60 \%$ of the labour force in the agricultural sector and account for over $80 \%$ of the labour force in food production (Snyder, 2000).

According to Bantebya (1992) the analysis of the societal impact of colonialism on women's economic activities suggests that this system was more detrimental for women than for men. After all, as Tadria (1987) observed, in Uganda men became part of the money economy while the women remained in the traditional sector. More specifically, Tadria (1987) argued that the economy was demarcated into two ideologically-aligned sectors: a local sector dominated by women and characterized by the sale of agricultural produce and other commodities around the homesteads, and the external sector dominated by men (men who migrate from their homes to engage in a variety of cash-generating activities). However, consciousness of discrimination by formal institutions has been on the rise in recent times in Uganda, and women's recent actions in politics (Goetz 2002; Tamale, 1998; Tripp, 1999, 2001), entrepreneurship (Snyder, 2000) and finance (Guwatudde, 1994) have been acknowledged by scholars. It is even suggested that these actions have created changes in gender ideology and power relationships at both the social-structural, and the household levels (Wakoko \& Lobao, 1996).

The economic crisis discussed above embraced the position of many Ugandan women, especially poor and peasant women, and weakened the basis of men's domination. With the decline of agriculture in the 1970s, which had been dominated by men, women learned to

\footnotetext{
${ }^{1}$ Wade and Tavris (1994) suggested that in a given society people hold a model or ideology of gender in which differences - and the basis and justification for differences between the sexes - are explicated.
} 
work outside of their homesteads. Thus, the National Resistance Movement's [NRM's] ascent to power was critical for entrepreneurship because it provided an encouraging environment that came with stability. In spite of these successes, Ugandan feminists groups complain that their countrywomen still have a long way to go before their efforts can bear any significant fruits. Although the Ugandan government has offered strong leadership in promoting women's rights - something the feminist groups admit - economic factors and the lack of supporting infrastructure continue to prevent women from achieving gender parity. A look at the recent Uganda Business Register survey sheds more light on this. For instance, in the report on the Uganda Business Inquiry of 2006/2007 the trade sector has the highest value added, namely 735 billion shillings. In addition, most businesses in this sector are in the one to four employees size band. However, although the report revealed that women entrepreneurs are mainly to be found owning the small businesses employing between one and four persons, the report treats and characterizes women workers in the economy as a minority, and explains the differences between men's and women's businesses as a result of women owners' lesser qualifications in terms of human, social and financial capital. This is paradoxical in the sense that women's progress in business ownership remains virtually invisible while a few demographic differences between men's and women's businesses are documented.

Similarly, Snyder (2000) observed that whereas women in Uganda now have the instruments for their political empowerment (enshrined in the 1995 constitution), women's economic power has not been boosted with similar positive policies and actions. Thus, such features make Uganda a particularly interesting place for research that addresses questions relating to experiences of female entrepreneurs.

\subsection{Study design and methods}

In this study, a choice was made to undertake a narrative type of inquiry because of three contributions that such an approach has been observed to make to research studies that emphasize interpretation, rather than prediction. First, it has been observed that narrative inquiry provides an internally consistent research approach when asking questions that relate to meaning and interpretation. Second, narrative inquiry is an appropriate methodology to capture complex interpretations of experience because it captures context and makes space for the multiple representations of various voices with a stake in the research (Dodge, Ospina, \& Foldy, 2005). Finally, it taps into the unique kind of knowledge that is communicated through stories.

In order to carry out a narrative form of inquiry, a number of research techniques were used to generate stories about participants' entrepreneurial experiences. This meant that the researcher listened carefully to how the participants thought about their lives, and critically to how traditional social sciences scholars conceptualized women's and men's lives. In terms of specific techniques, the study utilized in-depth interviews and short life-story forms of interviewing.

The sampling strategy followed that of Byrne (2004), broadly described as a purposive approach. That is, the selection of participants was based on information derived from already available sources of data, such as life-history documents relating to some of the 
participants. These sources were used to identify and locate appropriate participants who would then be approached and asked to participate. In some cases, snowball sampling (Byrne, 2004) was also followed. In the snowball strategy, some of the participants identified potential participants who were then approached by the researcher. As it has been observed in the literature, life-history research typically relies on small sample groups (Plummer, 2001). In this study, this meant that the participant sampling was based on considerations of data quality, rather than on statistical representativeness.

The current study made the following three assumptions that underpin three approaches to narratives discussed in this paper. The first assumption is that the stories of entrepreneurs tell about their experiences in their entrepreneurial activities give us access to the arguments, intentions, and meanings that support entrepreneurship (narrative as language). Secondly, entrepreneurship as practice is a legitimate source of knowledge from which to draw lessons about entrepreneurship, which can then be applied to other contexts (narrative as knowledge). The third assumption is that even though an entrepreneur may actively resist societal structures of power, those structures may influence their work, producing incongruence between discourse and practice (narrative as metaphor).

In analysing and interpreting narratives generated during the research process, three assumptions guided the researcher's methodological choices and influenced the nature of the analysis that was carried out. Drawing on narrative as language, the researcher used stories about participants' entrepreneurial experiences as the primary source for exploring entrepreneurship practices. Life-story interviews facilitated the flow of stories and storytelling. Similarly, in order to tap into the wisdom of participants' tacit knowledge- so important to the narrative as knowledge approach- the researcher's emphasis was focused on access to the insights embedded in entrepreneurs' day-to-day practices. Finally, drawing from narrative as metaphor, texts were critiqued and deconstructed, rather than taking them at face value in order to decipher implicit shared meanings of the participants' narratives of their experiences, and possibly offering alternative interpretations of accepted views in entrepreneurship discourse. Integrating elements from all these approaches, the study combined formal narrative analysis, thematic coding, and deconstruction techniques to analyse the data.

Case stories in the study database fell into three main categories: bigmanship, African woman, and cultural entrepreneurship stories. These are briefly described as follows: bigmanship was a category of stories of a culturally idealized form of masculine character. Such stories came in two forms. In the first form, which was referred to as hegemonic masculinity, entrepreneurs in this category provided stories that were consistent with the idea of a male archetypical entrepreneur. In the second form there were stories that provided a defensive grappling with gender issues. That is, in their accounts, emphasis was on gender neutrality as the criterion of fairness.

Women entrepreneurs' stories of challenges, perseverance and triumph constituted the second category which is referred to as African woman stories. More specifically, African woman stories came in two forms: gendered identity and manoeuvring space stories. In the gendered identity story category, there is a certain tentativeness regarding the position of men in the female entrepreneurs' business lives. This is reflected in their views of the 
current gender order and the accommodations they have to make. Manoeuvring space stories provide narratives of the ways in which gender is created and maintained in entrepreneurship discourse and practice. Cultural entrepreneurship stories provide narratives that tell of the meanings that entrepreneurs attach to, and the strategies for, success they adopt.

Rather than presenting case materials relating to entrepreneurial experiences of all the cases in the study, narratives of selected cases are presented in the next sections based on their potential to articulate issues relating to how female entrepreneurs maneouvre economic space. Therefore a detailed presentation and discussion of "bigmanship"; cultural entrepreneurship as well as gendered identity stories is beyond the scope of this chapter. Interested readers can refer to Kikooma $(2007 ; 2011)$.

\section{Manoeuvring economic 'space ${ }^{2,}$ for female entrepreneurs in Uganda}

While it's still largely the case that local gender ideologies shape women's economic opportunities in Uganda, this section presents two case studies of the extent to which female entrepreneurs maneouvre space within the male economic space. In the third case study entrepreneur's highlights one female entrepreneur's effort to initiate a self-help association in order to deal with the hostility that was being directed at her ability to crop-farm successfully in a village with culturally biased negative attitudes towards progressive methods of crop farming.

\subsection{Case study 1: The story of Uganda's 'woman publisher' ${ }^{3}$}

Robinah's story of how her company (RORASH Educational Publishers) was established starts with her experiences of working outside of the country with mostly international organizations. The characters in her story are family members, and the importance of family is apparent in her narratives. The success of the company is presented as being entirely dependent on her prior experiences while working with international publishers and the marketing skills acquired earlier. In her story, two characters from her family are mentioned in relation to how RORASH was established. Although their involvement in the process of establishing the company was acknowledged, it was taken for granted. For instance, the role of her brother is referred to only when describing the difficulty she had in communicating with Heinemann.

So Heinemann was looking for someone to represent them in Uganda and my former boss at Oxford University Press who [sic] I had worked with - the Heinemann staff in charge of Africa some years ago in Nigeria - recommended me. That is how the relationship started. I mean it was a long one. We missed each other, phones were not working. Sometimes they would travel to Kampala to come and meet me. I would not know how long the flight [would take?] I wouldn't know ... So trips were made and

\footnotetext{
2 The concept of space used here is based on Daly's (1991) social constructionist understanding of economic space as no longer presenting itself as a fixed totality constructed independently of its articulations with other social practices.

${ }^{3}$ That is how the media carried her story when it first came out (Kamugasa, 1998).
} 
one of the reasons we missed each other was communication owing at the time. The telecommunication system was very poor. Finally we met. The first obstacle was phones. I would have to make an appointment to talk to him through my brother. So my brother would give him something like one or two days to try and locate me. And when I appear maybe his phone is not working. You know. That sort of thing. So it was like a rat race. I don't know how to call it. Eventually we met and they appointed me as their agent in Uganda. Sole agent.

Robinah's story of the creation of RORASH as sole agent shows how the ingredients of entrepreneurship described in 'epic' terms (Gabriel, 1998) acquire meaning not in the abstract, but by being framed within the entrepreneurial stories. Unlike other stories, the interweaving between the business and the family in its dimensions of gender are not described in problematic terms. In fact, it is at this point that difficulties emerge that make the apparently gender-neutral epic story reveal its carefully constructed gendered nature. For example, the husband's involvement in the business at any stage in the creation process, as well as after its establishment, is not made explicit except to mention that through his contacts, they (he and Robinah) were able to convince someone to give them a loan to cover the foreign exchange of 10,000 US dollars that were allocated by government to RORASH when it was being established.

I had to look for the equivalent Uganda shillings to cover the allocation ... It was not a liberalized market. So I had to get the match up in Uganda shillings and the equivalent at the time. I think this was seven million shillings. So you can quickly work out the rate at the time. So I used my husband's connection. My husband used to work with Bank of Uganda before we left the country; and remember foreign exchange was by allocation. So many allocatees become his friends. In other words, there were many business people whose applications were fronted by him. So we wrote to one of the friends to lend us seven million shillings. The friend offered the money interest free with only one condition; that the stock will be warehoused by the lender. So, in so far as I would withdraw certain quantities, sell off, pay off, then I would be allowed to withdraw more. This was not a hindrance on my part. If anything, it was ... it helped us cut on costs because warehousing costs would have hindered us.

For the most part, Robinah's story 'silenced' other stories, so to speak. The husband and his role in the business are not visible in the narratives. It is only at some critical junctures that his contribution is made reference to. Moreover, she referred to the character of her husband in unpretentious terms.

I think here, let me talk about my husband. He is a globe-trotter, but he is a shy man and he is not very sociable. For him, he likes sports, exercises. Unlike him, I am social. I like both dancing and parties. But he has had no problem with my activities. He gives me guidance whenever I seek it. Being a banker, he finds this sort of work a bit boring.

Here we see how the narrator's 'theory in use' (Bruni et al. 2004) can give meaning to discursive practices of story-telling situated in a specific spatial setting. Robinah's framing of her story seems to put emphasis on her part of the story of RORASH, and in so doing lessens the possibility of the husband's part of the RORASH story being seen as necessary 
for anyone to understand the 'success' story of the company fully. That is why, although the husband's guidance is acknowledged as useful, it is presented as only given when it is sought for. Yet even the name RORASH (an acronym from the names of the couple Robinah and Rashid) suggests that the husband is, in fact, central to this business, something which is not apparent in Robinah's narratives.

From Robinah's narratives, what is said (but also from what may not have been said of the company's success story) is here seen as mobilizing, and even legitimating an entrepreneurial figure with an image of a "woman multi-million publisher" as one newspaper once described her business prowess (Kamugasa, 1998, p. 15). Thus, her narratives contribute to the hegemonic entrepreneurship discourse which glorifies an entrepreneurial male figure akin to what in the literature are masculine ideals related to risk-taking, authority, sexuality and paid work (Connell, 1995, 2001).

The work of Weedon (1987) may be instructive in examining the above examples. According to Weedon (1987), a post-structuralist perspective allows an investigator not just to evaluate the material possibilities available to women, but it also gives the investigator a sophisticated account of how discourse steeped in particular ideologies may make choices impossible or contradictory. In the case above, Robinah recognizes herself as an independent, successful business woman, but does not recognize the ways in which such a subject position is constructed and, in the words of Weedon $(1987$, p. 310$)$, "assumes she is the author of the ideology which constructs her subjectivity".

\subsection{Case study 2: A woman who ventured into a non-traditional domain}

For a long time in Uganda the business of driving a public transport vehicle, let alone owning one, was a "man's thing'. However, it was not to remain so forever. In November 1997 the New Vision newspaper wrote that when Victoria Muwanga decided to venture into the transport business like any other ambitious Ugandan, little did she know that it would be such a big issue. Nine months later, she not only captured the traffic officers' attention, but also won public acclaim (Rwomusana, 1997). The media described the shock on a passenger's face on realizing that the driver was a woman

A matatu [minibus] passenger bound for Ntinda from Kampala was deeply impressed with his driver's safety consciousness. "Drives carefully. Does not screech the brakes," he commented as he moved forward to congratulate the driver. Astonished, he blurred out, “Are you really a woman?" (Rwomusana, 1997, p. 14).

Driver Victoria is one of the female entrepreneurs in Uganda who tried to find new ways to enhance her livelihood. Although she acknowledged that her job (of driving the matatu [mini bus] - the most common form of transport) had been labelled as a 'men only' job in Uganda, she believed that this was changing as her passengers like 'her driving'.

As Kampala's first female matatu owner-driver, and probably also first in Uganda, her story compelled Snyder (2000) to include her in the book on "Women in African economies". Describing her experience in her new job, Victoria said: "You need to see the shock on people's faces, especially men, who enter my bus unknowingly and later discover a woman behind the wheel. But now they like my driving" (Snyder, 2000, p. 187). 
Snyder hailed her for bravery and said that Victoria is unwilling to be sidelined because she is a widow and is determined not to become the burden to her family and community. When some men say that she is a muyaye 4 her reaction is clear:

I do not care because I know I am not a muyaye; I am just earning an honest living. I have to survive. Women should not fear what people say. It is what you think, how you carry yourself that matters. Nothing is going to stop you from being a woman, a wife, a mother just because you drive a taxi! (Snyder, 2000, pp. 187-188).

Victoria plies the Ntinda-Kampala route, a service that earned her a vocational award from the Rotary Club of Mengo. "This is great. I did not expect such recognition and respect from these young people," she told the New Vision newspaper. She said the recognition made some members of her family who had been reluctant to accept her new profession, change their minds.

My eldest son who had insisted that his friends would laugh at him is now happy with my achievement. The big girl had encouraged me from the start but had probably not expected such an honour in a short time.

But why was she driving? Born into a polygamous family whose head was a medical assistant, Victoria tried her hand at many things. She dropped out of her secondary school education at senior three level upon her father's death. With a helping hand from a maternal uncle, she later enrolled for a nursing course in Nsambya, but this hope soon withered for the ambitious young woman when one time she $(\mathrm{ad})$ ventured into a discotheque at night and was suspended together with friends. "Naturally, my uncle was disappointed, but being a forgiving parent that he is, he sent me to Nakawa to study secretarial," she said in her interview with the New Vision newspaper.

Victoria learnt driving as a young girl while living at her uncle's place, a man whom she regards highly. "My uncle was a minister and one could bribe his drivers to teach you how to drive. The first vehicle I drove was a Mercedes-Benz," she revealed. Victoria tried farming and food businesses for a while until a friend suggested buying a taxi. However, when she bought a taxi and gave it to a driver, with a relative to oversee, the two connived to cheat her. "For a whole year I got no money while the vehicle became ramshackled," she revealed. The hired drivers were using the vehicle to transport goats, matooke [green bananas] and other produce from many hundred miles away. "When I grew tired of all that, I thought that I could surely drive," she explains. She went to UTODA (Uganda Taxi Operators' and Drivers' Association) offices for a driving permit, and after undergoing several tests she was commissioned to drive. "It is best to be your own driver", she admits. Victoria believes there is no reason not to drive and hiring 'young boys', most of whom have never handled a million shillings before. "They can cheat an owner out of a hundred thousand shillings, then

\footnotetext{
${ }^{4}$ In Uganda, more particularly in towns, muyaye is a derogatory term that is used to insult someone. According to Obbo (1991), the word bayaye (the plural of muyaye) originally referred to the unruly, marijuana [njaye]-smoking young men from Kyagwe county in Southern Uganda during the reign of Kabaka [King] Mwanga. They were mostly rebellious youths who rebelled against their parents and teachers, and sought a short-cut means of earning a living. Currently, they are stereotypically seen as 'unemployed', shabbily dressed, and foul-mouthed, operating in city market places and taxi and bus parking lots.
} 
think they are very rich, stay at home until the money is gone and then come crawling back," she explains.

What this case study reveals is that while women, on the one hand, are faced with reduced access to both material and other resources, and are subjected to a large number of oppressing mechanisms legitimized by patriarchal structures (Snyder, 2000), they are far from being passive individuals. On the contrary, Victoria's case shows that they are reflective and active agents, often with both influence and authority within their daily reality. From her story it is clear that gender struggle is integral to all expressions of gender relations, though it can take various implicit and explicit forms. Victoria grew up struggling with expectations of her as a female with specific roles. For instance, these expectations influenced which profession she was expected to join, courses that she studied at school and what skills she acquired as a young girl growing up in a male-dominated world. Indeed, she studied nursing, then studied with Irish nuns in Nsambya Hospital and later studied a secretarial course; all of which were considered as training for 'women's jobs' (Snyder, 2000). Later, she tried different sorts of businesses, including operating a restaurant, farming, as well as food businesses. These are, again, 'women's jobs'. None of these were in transport.

The main message of this case study is in the way it brings to the foreground a discord in the traditional role patterns revealed through her entrepreneurial activities. In addition, the traditional notions of gender identity and relations are brought into question. In her case, for instance, girls would normally not be expected to learn how to ride a bike, let alone drive a vehicle, which would later become a critical skill in her current business life. Her story calls into question traditional notions of masculinity in discourse of entrepreneurship and suggests that men gain advantages from the culturally-dominant ideal of masculinity centred around authority, physical toughness and strength, and paid work (Pilcher \& Whelehan, 2004), but that few men actually live up to it as the last paragraph in Victoria's narratives demonstrates.

\subsection{Confronting negative cultural interfaces ${ }^{5}$ using entrepreneurship}

Some of the most familiar cultural interfaces in Africa are to be found in work by Munene, Schwartz and Kibanja (2005) who attempted to characterize the social and cultural life in relation to poverty in Uganda. They described a particular focal entrepreneurial individual with social capital in a community development association. They explained how in that case study, a focal individual joined a new community after the Ugandan civil war (during the period 1981-1986) and brought with her new ways of crop-farming. In this particular community members experienced perennial food shortages because the rocky landscape with saline topsoil on which they farmed was infertile. The authors noted that for unknown

\footnotetext{
${ }^{5}$ According to Munene, Schwartz and Kibanja (2005), an interface is an abstraction referring to an interpersonal or an intergroup space, which is generated by the meeting of two parties (agents) in the process of an exchange. It is composed of the interactional outcome of motivations, beliefs, perceptions and underlying experiences that each of the parties brings to an exchange. According to Munene et al. (2005), there are many types of cultural interfaces which may be viewed as negative or positive for economic development in Africa.
} 
reasons, the community had never utilized the services of an agricultural extension worker to show them how to overcome this problem. Overtime they had come to believe that it was impossible to get good harvests in their village and they were suspicious of anyone who claimed it could be done.

The community members who had been struggling to survive off their saline soil immediately noticed the new settler's success. Part of the village thought that the newcomer to their community was a miracle worker who was using supernatural powers to achieve 'bumper' crop harvests. The more extreme community members holding this view thought that the newcomer had been excommunicated from her former village because she was a witch "since only a witch could succeed where everyone else was failing" (Munene et al, 2005, p. 89). The settler became the talk of the village and of even neighbouring villages and expressing negative evaluations of her. To deal with the hostility that was being directed at her because of her ability to crop-farm successfully, she decided to train the villagers in what she referred to as environmentally sustainable agriculture. To achieve this objective she initiated a self-help association called Twegombe (let us be ambitious) Development Association through which she could impart her skills. According to her, the people of the village were neither hardworking nor progressive. Baali tebegomba (they had no ambition and no admiration for those who were successful), the new settler said. In time women around the village heard and saw what members of Twegombe were doing and they gradually joined one by one and, according to Munene et al. (2005), the association has become one of the most progressive development associations in the community.

For a study on entrepreneurship in a context such as the one described above, what one can note is that entrepreneurial individuals not only seek to combine various resources, but also combine various social relationships in order to create and generate value in the community. An interesting insight in the case study just described above is the role of the focal entrepreneurial individual in changing community mores and social values through unpaid self-motivated social functions, as well as through the exchange of information on villager behaviour and through financial incentives. Moreover, she saw that in order for her to do well, she needed to ensure that the village did well, too.

\section{Beyond a sole economic discourse}

Recently, there have been calls to entrepreneurship as a more complex phenomenon than is allowed by its narrow formulation as an economic activity (Calàs, Smircich \& Bourne, 2009). They question whether the economic emphasis behind entrepreneurship constructs in that traditional perspectives, as well the constructs themselves, represent appropriately all the may constitute the domain of entrepreneurship, including its nature as phenomena. The forms and practices of entrepreneurship presented in this chapter allow us to include other discourses such as cultural and civic discourses besides the economic one. The first two case studies provides us with insight into how individual men and women in the study context perform gender in daily interaction. This was similar to a study by Gherardi (1996), who showed that there was a discursive limitation to what subject positions were available for professional women in male working environments. As the two studies show, the women remain as outsiders. These studies do not only simplify explanations for women's 
subordination to what individual men and women did or how they were but also accounted for the choices available through the discursive order. Even when studying individuals "the social" was accounted for.

The social dimension focuses on the social process that constitutes entrepreneurship. The third case study example shifts the focal point from singular entrepreneurs to the everyday processes where multiple actors and stakeholders are made visible as related to entrepreneurship. As Steyaert and Katz (2004) observed, by relating entrepreneurship to society, we become aware of the scenes, aspects and stakeholders we have privileged taking part in entrepreneurial processes and draw attention to other possibilities to tell stories of entrepreneurship.

\section{Conclusions}

Whereas the contributions of this study relate to the broadening of entrepreneurship knowledge in general, case materials presented and conceptual lenses applied to analyze them help inform general theory and explain conditions that deviate from traditional theoretical explanations of the phenomenon. The descriptions and discussions in this study highlight a contrasting process, namely examining how entrepreneurs in the case studies presented were practising entrepreneurship and gender in forms that can be considered alternative (if not opposite) to those normally prescribed by a model of hegemonic masculinity.

It has been acknowledged that an account of the processes that position people as 'men' and 'women' within business practices and as entrepreneurs within gendered practices is an approach still underutilized in the literature (Bruni et al., 2004). In this regard, the use of gender and cultural interfaces as conceptual tools with which to examine entrepreneurship, as both an economic phenomenon, as well as a social practice among historically situated men and women entrepreneurs in Uganda can be seen as a first step towards rethinking female entrepreneurship discourse in this particular context.

\section{References}

Ahl, H. (2006). Why research on women entrepreneurs needs new directions. Entrepreneurship: Theory and Practice, 30(3), 595-621.

Armstrong, P. (2001). Science, enterprise and profit: Ideology in the knowledge driven economy. Economy and Society, 30(4), 524-52.

Arnfred, S. (2004). Gender research in Africa: dilemmas and challenges as seen by an outsider. In A. Arnfred, B. Bakare-Yusuf, E. Kisiang'ani, D. Lewis, O. Oyewumi and F.C. Steady (Eds.), African gender scholarship: Concepts, methodologies and paradigms (pp.82-100). Dakar: CODESRIA

Bantebya, G. K. (1992). The role of women in petty commodity production and commerce: A case study of rural peasant women in Uganda. Eastern African Social Science Research Review, 8(2), 1-19.

Billig, M. S. (1994). The death and rebirth of entrepreneurialism in Negroes Island, Philippines: A critique of cultural theories of enterprise. Journal of Economic Issues, $28(3), 659-678$. 
Blake, M. K. \& Hanson, S. (2005). Rethinking innovation: context and gender. Environment and Planning, 37, 681-701.

Bruni, A., Gherardi, S. and Poggio, B. (2004a). Doing Gender, Doing Entrepreneurship: An Ethnographic Account of Intertwined Practices. Gender, Work and Organization, 11(4), 406-429.

Bruni, A., Gherardi, S. and Poggio, B. (2004b). Gender and entrepreneurship: An ethnographic approach. London: Routledge.

Byrne, B. (2004). Qualitative interviewing. in C. Seale (Ed) Researching society and Culture (2nd Ed) (pp. 179-192). London: Sage.

Calàs,M. B., Smircich, L. \& Bourne, K.A.( 2009). Extending the boundaries: reframing "entrepreneurship as social change" through feminist perspectives. Academy of Management Review, 34(3), 552-569.

Connell, R.W. (2001). Introduction and overview. Feminism and Psychology, 11(1), 5-9.

Connell, R.W. (1995). Masculinities. Cambridge: Polity Press.

Davidsson, P., \& Wiklund, J. (2001). Levels of analysis in entrepreneurship research: current research practice and suggestions for the future. Entrepreneurship: Theory and Practice, 25(4), 81-99.

Daly, G. (1991). The discursive construction of economic space: Logics of organization and disorganization. Economy and Society, 20(1), 70-102.

Dodge, J. Ospina, S. M. \& Foldy, E.G. (2005). Integrating rigor and relevance in public administration scholarship: the contribution of narrative inquiry. Public Administration Review, 65(3), 286-300.

Gabriel, Y. (1998). The use of stories. In G. Symon and C. Cassell (Eds.), Qualitative Methods and Analysis in Organizational Research: A Practical Guide (pp. 135-160). Thousand Oaks: Sage.

Gherardi, S. (1996). Gendered organizational cultures: narratives of women travellers in a male world. Gender Work and Organization, 3(4), 187-201.

Goetz, A. M. (2002). No short cuts to power: constraints on women's political effectiveness in Uganda. Journal of African Modern Studies, 40(4), 549-575.

Guwatudde, C. et al (1994). Women's informal credit groups: An exploratory study of some experiences in Kampala. Kampala: Ministry of Women in Development, Culture and Youth.

Harding, S. (1991). Whose science? Whose knowledge? Thinking from women's likes. Ithaca, NY: Cornell University Press.

Kamugasa, K. A. (1998). Women: the multi-million publisher. The New Vision, April 28, pp. 15.

Kikooma, J. (2007). Doing entrepreneurship in Uganda: the social construction of gendered identities among male and female entrepreneurs. Unpublished PhD thesis. University of Cape Town, South Africa.

Kikooma, J. (2011). Negotiating enterprising identities: African woman entrepreneur stories of challenge, perseverance and triumph. China-USA Business Review, 10(7), 573-586.

Kolawole, M. (1997). Womanism and African consciousness. Trenton, NJ: Africa World Press.

Lewis, D. (2001). African feminisms. Agenda, 50, 4-10.

Low, M.B., \& Macmillan, I.C. (1988). Entrepreneurship: past research and future challenges. Journal of Management, 14, 139-162. 
Maynard, M. (2004a). Feminist research. In M.S. Lewis-Beck, A. Bryman \& T. F. Liao (Eds.), The SAGE Encyclopaedia of Social Science Research methods (pp. 378-381). London: Sage.

Maynard, M. (2004b).Feminist issues in data analysis. In C. Hardy and A. Bryman (Eds.) Handbook of data Analysis (pp. 131-145). London: Sage.

Mills, A.J. (1988). Organization, gender and culture. Organization Studies, 9(3), 351-369.

Moore, D.P. (1990). An examination of present research on the female entrepreneursuggested research strategies for the 1990s. Journal of Business Ethics, 9(4-5), 275-281.

Munene,J.C., Schwartz, S.H. \& Kibanja, G.M. (2005). Escaping from behavioural poverty in Uganda. Kampala: Fountain.

Obbo, C. (1991). Women, children and a 'living wage'. In H.B. Hansen and M. Twaddle (eds.), Changing Uganda: the dilemmas of structural adjustment and revolutionary change (pp. 91-122). London: James Currey.

Ogbor, J. O. (2000). Mythicizing and reification in entrepreneurial discourse: Ideologycritique of entrepreneurial studies. Journal of Management Studies, 37(5), 605-635.

Overa, R. (2003). Gender ideology and manoeuvring space for female fisheries entrepreneurs. Research Review, 19(2), 49-66.

Pereira. C. (2002). Women organizing and feminism: Linking local and global. Presentation at CRD Damina School, 18th- 30th August 2002, Duala Hotel, Kano, Nigeria.

Pilcher, J., \& Whelehan, I. (2004). 50 Key Concepts in Gender Studies. London: Sage.

Plumer, K. (2001). Documents of Life: An Invitation to a Critical Humanism. London: Sage.

Rindova,V., Barry, D. \& Ketchen, D.J.( 2009). Introduction to special topic forum: Entrepreneurship as emancipation. Academy of Management Review, 34(3), 552-569.

Rwomusana, G. (1997). She ventured into the male domain of taxi driving and got an award. The New Vision, November 23, pp. 14.

Sadiq, F. (2002). Changing gender dynamics. CODESRIA Bulletin, 3E4, 35-41.

Shane, S.A., \& Venkataraman, S. (2000). The promise of entrepreneurship as a field of research. Academy of Management Review, 25(1), 217-226.

Snyder, M. (2000). Women in African economies: From burning sun to boardroom. Kampala: Fountain.

Ssetuba, I. (2002). The hold of patriarchy: an appraisal of the Ganda proverb in the light of modern gender relations. Presented at the Cairo Gender Symposium organized by CODESRIA/ARC, Cairo $7^{\text {th }}-10^{\text {th }}$

Stevenson, L. (1990). Some methodological problems associated with researching women entrepreneurs. Journal of Business Ethics, 9, 439-446.

Steyaert, C., \& Hjorth, D. (2007). Entrepreneurship as social change. Cheltenham, UK: Edward Elgar.

Steyaert, C \& Katz, J. (2004). Reclaiming the space of entrepreneurship in society: geographical, discursive and social dimensions, Entrepreneurship $\mathcal{E}$ Regional Development, 16, May, 179-196

Tadria, H.M.K. (1987). Changes and continuities in the position of women in Uganda. In P.D. Wiebe and C.P. Dodge (eds.) Beyond crisis: development issues in Uganda (pp. 7090). Kampala: Makerere Institute of social Research.

Touré, A., Barry, M.C., \& Diallo, P. (2003). Two faces of African feminism. CODESRIA Bulletin, (1), 2-3. 
Tripp, A. M. (2001). The politics of autonomy and cooptation in Africa: The case of Ugandan women's movement. Journal of African Modern Studies, 39(1), 101-128.

Tripp, A. M. (1999). Women and politics in Uganda. Madison: University of Wisconsin Press; London: James Currey; Kampala: Fountain.

Uganda Bureau of Statistics. (2007). A report on the Uganda business register 2006/2007. Kampala: Author.

Wade, C., \& Tavris, C. (1994). The longest war: Gender and culture. In W.J. Lonner and S.R. Malpass (Eds.), Psychology and culture (pp. 121-126). Boston: Allyn \& Bacon.

Wakoko, F., \& Lobao, L. (1996). Reconceptualizing gender and reconstructing social life: Ugandan women and the path to national development. Africa Today, 43(3), 307322.

Weedon, C. (1987). Feminist Practice and Poststructuralist Theory. Oxford: Blackwell. 


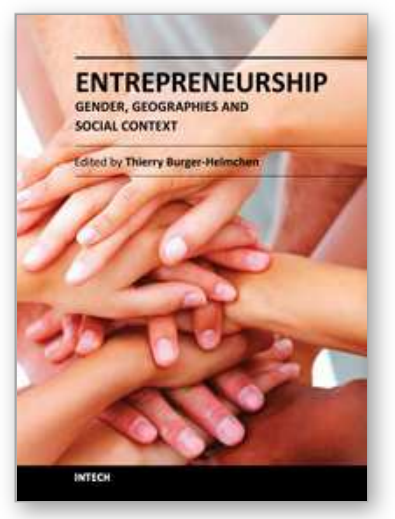

\author{
Entrepreneurship - Gender, Geographies and Social Context \\ Edited by Prof. Thierry Burger-Helmchen
}

ISBN 978-953-51-0206-9

Hard cover, 306 pages

Publisher InTech

Published online 14, March, 2012

Published in print edition March, 2012

Entrepreneurship is a main driver of economic growth and of social dynamics. However, some basic characteristics like the gender of the entrepreneur, the geographical location, or the social context may have a tremendous impact on the possibility to become an entrepreneur, to create a firm and to prosper. This book is a collection of papers written by an array of international authors interested in the question of entrepreneurship from a gender point of view (male vs female entrepreneurship), a geographical point of view (Africa, Europe, America and Latin America, Asia...) or a specific social context point of view (agricultural economy, farming or family business, etc.).

\title{
How to reference
}

In order to correctly reference this scholarly work, feel free to copy and paste the following:

Julius Kikooma (2012). Gender and Entrepreneurship in Uganda: Women Manoeuvring Economic Space, Entrepreneurship - Gender, Geographies and Social Context, Prof. Thierry Burger-Helmchen (Ed.), ISBN: 978953-51-0206-9, InTech, Available from: http://www.intechopen.com/books/entrepreneurship-gendergeographies-and-social-context/gender-and-entrepreneurship-in-uganda-women-manoeuvring-economicspace

\section{INTECH}

open science | open minds

\section{InTech Europe}

University Campus STeP Ri

Slavka Krautzeka 83/A

51000 Rijeka, Croatia

Phone: +385 (51) 770447

Fax: +385 (51) 686166

www.intechopen.com

\section{InTech China}

Unit 405, Office Block, Hotel Equatorial Shanghai

No.65, Yan An Road (West), Shanghai, 200040, China

中国上海市延安西路65号上海国际贵都大饭店办公楼 405 单元

Phone: +86-21-62489820

Fax: +86-21-62489821 
(C) 2012 The Author(s). Licensee IntechOpen. This is an open access article distributed under the terms of the Creative Commons Attribution 3.0 License, which permits unrestricted use, distribution, and reproduction in any medium, provided the original work is properly cited. 